Send your letters to the Editor,

British Dental Journal,

64 Wimpole Street

London

W1G 8YS

Email bdj@bda.org

Priority will be given to letters less than 500 words long.

Authors must sign the letter, which

may be edited for reasons of space.

\section{STEM CELL VISITS}

Sir, I note the report of research in which Tamaoki et al. have successfully induced pluripotent stem cells from dental pulp cells (BDJ 2010; 209: 5). The original discovery of stem cells in the dental pulp was by S. Shi's team at the NHI, Maryland, USA in 2003.

As a direct result of this research a process for extracting, magnifying and storing these cells was patented and became the cornerstone of the process of Bioeden Ltd, Austin, Texas which stores cells naturally acquired from recently shed deciduous teeth. This is the only known way of achieving access to healthy stem cells which is both natural and non-invasive, consequently meeting with the approval of all mainstream religions and cultures.

Consequently, stem cells are now stored for thousands of children and young adults from more than 20 countries and research-based medical therapies using dental pulp cells have successfully taken place already in Italy and Mexico City. ${ }^{2}$

Bioeden Ltd currently has its international headquarters in Daresbury, Cheshire - and, as would be expected, has extensive relationships with dentists both in the UK and overseas.

In addition to my directorship with Bioeden Ltd I also enjoy my continuing involvement in dental practice, and should any of the journal's readers like to visit our laboratories and hear more about our company I should be delighted to organise such a visit for them.

D. James

Director, Bioeden Ltd,

Chester Cosmetic Dental Centre david.james@bioeden.com

1. Miura M, Gronthos S, Zhao M et al. SHED: stem cells from human exfoliated deciduous teeth. Proc
Natl Acad Sci U S A 2003; 100: 5807-5812. 2. d'Aquino R, Papaccio G, Laino G, Graziano A. Dental pulp stem cells: a promising tool for bone regeneration. Stem Cell Rev 2008; 4: 21-26.

DOI: $10.1038 /$ sj.bdj.2010.821

\section{DEVELOPING THE TEAM}

Sir, the British Society of Dental Hygiene and Therapy (BSDHT) recently hosted the 18th International Symposium on Dental Hygiene (ISDH) under the auspices of the International Federation of Dental Hygienists in Glasgow. It attracted over 1,100 people from 36 countries making it the largest international symposium to date. It was an event made possible by the excellent teamwork from many people and organisations. The scientific programme proved first class and delegates enjoyed some of the most information rich continual professional development it's possible to generate.

ISDH 2010 enjoyed considerable support from the dental industry who not only participated in the exhibition but the following were also principal sponsors of the symposium: Colgate, Johnson and Johnson, Philips, Procter and Gamble Oral Health Care, GlaxoSmithKline, Tepe NSK, Sunstar and Dentsply.

The British Dental Association (BDA) along with the British Dental Trade Association (BDTA) can also be thanked for their support. In fact this was highlighted by our international colleagues, how in the United Kingdom we are truly developing the dental team and the co-operation between all dental professionals is becoming the envy of other countries. At a time of uncertainty within the profession, from a global prospective what is certain is that in the United Kingdom we are being recognised as the world leader in developing the role of the dental team. Credit must go to the BDA, BDTA and the Department of
Health for continuing to facilitate change and recognise the true value of the role of all members of the dental team.

M. Wheeler

ISDH 2010 Event Director DOI: 10.1038/sj.bdj.2010.822

\section{DOWN THE DRAIN}

Sir, in this time of austerity, is the profession acting ecologically responsibly? No doubt others have mused over this conundrum, and the possible impact of HTM 01-05. According to the BDA there are around 11,000 dental practices in the country, and no doubt hospital and community services will add a further 500 units. If we consider water usage, each unit following HTM 01-05 will have an ultrasonic bath, a washer disinfector and an autoclave. Water usage will vary between models, but as an example they could use 6, 14.5 (per cycle) and 3.5 (discharged at the end of the day) litres per day. If five cycles of the washer disinfector are undertaken, a total of 82 litres of water (ignoring that from the air rota use) will go down the drain each day per unit. A total of 943,000 litres from all dental units per day. As an Olympic size swimming pool holds approximately 2,500,000 litres of water, we could be discharging over one third of a swimming pools volume of water down the drain each day. No wonder the reservoirs are drying up. In addition to this there is the 2,800 litres of ultrasonic cleaner and 2,800 litres of washer disinfector detergent each day, both of which the water companies will have to remove before the water can be reused or discharged back into the environment. This leads on to consideration of the weight of chemicals and energy used in providing the water fit to drink in the first place, which is quite considerable. 
The sterile water we use for the autoclave is provided in one litre plastic bottles, of which we use four each day, draining 3.5 litres off at the end of the day. Following the above assumptions, a total of 40,250 litres would go down the drain, and 46,000 bottles used each day. The cost in energy in production of the sterile water: to extract water from the ground, to distil it, and fill the bottles; and the energy required to produce the plastic, convert it into a bottle, transport it, and sterilise its contents, are substantial. Further the 46,000 bottles per day, will require collecting and recycling, or will end up being transported and taking up space in a land fill site.

Although my calculations may be well wide of the mark, hopefully they provide further food for thought. However it is undoubtedly true that HTM 01-05 has greatly increased dentistry's carbon footprint in this country.

\section{Dugmore}

Leicester

DOI: 10.1038/sj.bdj.2010.823

\section{POSITIVE SPUTUM}

Sir, we read with interest the paper Primary tuberculosis masquerading as gingival enlargement (BDJ 2010; 208: 343-345).

Tuberculosis has a very high incidence in developing countries. According to WHO estimates 9.27 million new cases of tuberculosis (TB) occurred in 2007 with around 55\% of global cases arising in Asia (South East Asia and Western Pacific regions), which is attributed to poor hygiene conditions.

The authors of the paper presented a case of primary tuberculosis of the gingiva. Such a condition is considered a rare entity affecting approximately $0.05-$ $5.00 \%$ of patients with $\mathrm{TB}^{2}$ as the oral cavity is considered to be immune due to local immunity of the mucous membrane. ${ }^{3}$ However, an increasing incidence of TB (due to Aids and emerging multidrug resistant strains) means that we are likely to see many cases of tuberculosis in the oral cavity in future, so that TB should be considered as a differential diagnosis. The most usual presentation is as an ulcer on the tongue, gingival or buccal mucosa and as a radiolucency when bone is affected. Since the ulcers usually mimic squamous cell carcinoma, a diagnosis becomes more challenging. ${ }^{4}$ Mechanical tears and trauma in the oral cavity are considered one of the aetiological factors for inoculation of bacteria in the oral tissue from sputum. But surprisingly, there are very few cases of secondary tuberculosis in spite of a high incidence of sputum positive cases.

The authors have found positive sputum in their case. Acid fast bacilli can be found in saliva in a case of primary tuberculosis of the oral cavity but not in sputum. Positive sputum points to TB of pulmonary origin although sometimes, $\mathrm{TB}$ of the bronchioles is not evident on radiographs. To rule out that possibility, bronchoscopy or CT scan is mandatory. We therefore believe that the presented case is of secondary tuberculosis of the oral cavity.

\section{S. Gandhi, N. Gandhi, S. Bither} By email

1. WHO. Global tuberculosis control-epidemiology strategy, financing. Geneva: WHO, 2009.

2. Wang W C, Chen J Y, Chen Y K, Lin L M. Tuberculosis of the head and neck: a review of 20 cases. Oral Surg Oral Med Oral Pathol Oral Radiol Endod 2009; 107: 381-386

3. Nohrstrom E, Kentala E, Kuusela P, Mattila P S Tuberculosis of the head and neck in Finland. Acta Otolaryngol 2007; 127: 770-774.

4. Meng C M. Tuberculosis of the mandible. J Bone Joint Surg Am 1940; 22: 17-27.

DOI: $10.1038 /$ sj.bdj.2010.824

\section{DENIED A REPLY}

Sir, I read with interest the letter Anonymity rights (BDJ 2010; 209: 105), recounting a false allegation of molestation from a female patient. I have been in general practice since 1986 and I always work with my door open and a nurse in the surgery. Five years ago a female patient had a lengthy crown prep procedure during which the surgery door was open and my nurse was present. This lady waited for one month and then reported to the police that she had been raped whilst in the chair. She took two days of their time and her story was so garbled that they refused to take the matter any further. My frustration was and still remains that I was advised that I must not contact her at all costs and I had no right of reply. She did not, as far as I know, broadcast her allegations more widely. She has now five years later sent a letter threatening to end my career as she has found a retired journalist who is going to champion her cause, and signed her letter 'one of your victims'. Throughout the time I have had to live under the threat of her 'going public'. I suppose it is the risk we take donning a white coat, and I was relieved that she had chosen something so extreme to fantasise about. The local police were quite supportive and wanted to prosecute her for wasting police time, however, they are not allowed to unless she withdraws her allegation, which she refuses to do.

There is no way I can prove nothing happened or prevent someone else doing something similar. I could install a video recorder to tape every working session, but I would have hours of tape to catalogue and keep forever. Anonymity for the accused is viewed as unnecessary by our law makers because the rates of false accusation for rape and sexual offences is no higher than for any other crime. The stress that such an accusation causes cannot be described or the sense of how unjust it is when we are denied a right of reply.

Name and address supplied DOI: 10.1038/sj.bdj.2010.825

\section{SILLY SEASON}

Sir, well the 'silly season' must be upon us! So I gather the GDC is considering removing our right to use the courtesy title 'Dr'. I think there are some very important comments to make on this issue.

First the GDC should not be wasting their time and resources over an issue that was sorted out after decades of debate 14 years ago. I gather that the excuse for this 'debate' is that the courtesy title 'Dr' can confuse the public and mislead them into believing dentists are medically qualified!

So, have there been any issues where a member of the public has been misled by this courtesy title in the last 14 years? NO.

The courtesy 'Dr' title for dentists is used by the majority of countries in the world. The people in these countries do not seem to have any problems over this, and there do not appear to have been any issues of the international or EU public being misled in any way. The GDC is implying that the British public are stupid - or certainly not as discerning as the rest of the world!

The majority of countries in the EEC refer to their dentists as 'Dr'. The dental qualifications of EU countries are 